\title{
Effect of firing temperature on physico-mechanical properties of contemporary clay brick productions in Lalitpur, Nepal
}

\author{
N. B. Bohara ${ }^{1}$, D. B. Ghale ${ }^{1}$, Y. P. Chapagain ${ }^{1}$, N. Duwal ${ }^{2}$ and J. Bhattarai ${ }^{1 *}$ \\ ${ }^{1}$ Central Department of Chemistry, Tribhuvan University, GPO Box 2040, Kathmandu, Nepal \\ ${ }^{2}$ St. Xavier College, Thapathali, Kathmandu, Nepal
}

Received: 20 March 2019

Revised: 24 June 2019

Accepted: 01 July 2019

DOI: https://doi.org/10.3329/bjsir.v55i1.46731

\begin{abstract}
Effect of firing temperature on some physico-mechanical properties of ten brick samples, those were composed by feldspars, quartz, alumina-rich spinel, primary mullite and hematite phases, was investigated in accordance with ASTM standards. The brick samples fired between $700^{\circ}$ to $1100^{\circ} \mathrm{C}$ showed $11-23 \%$ water adsorptivity (WA), $19-37 \%$ apparent porosity (AP) and $1.50-1.65 \mathrm{~g} / \mathrm{cm}^{3}$ bulk density (BD) indicate good physical properties. The maximum compressive strength (CS) of the fired-bricks at $950^{\circ}$ to $1000^{\circ} \mathrm{C}$ was found to be between 15.6 and $17.1 \mathrm{MPa}$. At $700^{\circ}-1000^{\circ} \mathrm{C}$ firing temperatures, the CS of these bricks is found to be increased exponentially with decreasing of both WA and AP, however it is found to be increased with increasing the BD. Consequently, it can be said that there is good correlation between mechanical and physical properties of the fired-brick samples up to the firing temperature of $1000^{\circ} \mathrm{C}$.
\end{abstract}

Keywords: Clay brick; Sintering; Compressive strength; Water absorption; Apparent porosity; ASTM methods

\section{Introduction}

The clay brick is perhaps one of the man-made durable structural materials so far and their use has been increased since Mesopotamian, Egyptian and Roman periods (Fernandes et al., 2010). In modern age, its widespread use is mainly due to the availability of clay minerals in most countries of the world. The best quality of bricks depends on the types of clay raw materials used and the firing temperature during their production, because both of these parameters affect the quality and durability of bricks (Mostaghelchi et al., 2013; Johari et al., 2010; Rasmussen et al., 2012; Dunham et al., 2001; Dondi et al., 1999). It is said that the durability (i. e., mechanical strength) of the clay brick samples depends mainly on their mineralogical composition and physical properties like water absorption capacity, porosity, density and so on (Bordia and Camacho-Montes, 2012). The mineralogical, physical and mechanical properties of the fired bricks are generally interrelated to each others. It was reported that the firing temperature was found to be one of the key factors to modulate the physico-mechanical properties of different types of ceramic bodies like bricks (Ajala et al., 2017a, 2017b; Velraj et al., 2009; Karaman et al., 2006), but not the firing rate on kaolinite-based ceramics (Njoya et al., 2017). The physical properties of clay brick samples and their mechanical strength were investigated at different firing temperatures and the samples fired at $1100{ }^{\circ} \mathrm{C}$ showed the best mechanical properties (Johari et al., 2010; Aramide, 2015; Dodoo-Arhin et al., 2013; Martin-Marquez et al., 2010; Ghorbel et al., 2008; Yongue-Fouateu et al., 2016).

On the other hand, the porosity and water absorbtivity of the fired clay bodies were reported to decrease with increasing their firing temperature, while the density and Young's modulus of elasticity of the clay bodies were increased with increasing the temperature (Aramide, 2015; Yongue-Fouateu et al., 2016). The porosity influences quite dramatically the mechanical strength of ceramic bodies like bricks; for example, it is not uncommon that $10 \%$ volume porosity generally helps to decrease the flexural strength by $50 \%$ of the measured value for the nonporous materials (Callister, 2007; Coble and Kingery, 1956). The flexural strength $\left(\sigma_{\mathrm{F}}\right)$

*Corresponding author e-mail: bhattarai_05@yahoo.com 
generally decreases exponentially with volume fraction porosity (P) (Callister, 2007) as given equation (1) below, where $\sigma_{0}$ and $n$ are experimental constants.

Flexural Strength $\left(\sigma_{F}\right)=\sigma_{0} \times \exp (-n P)$

The durability assessment of different types of clay bricks is mainly based on their technical physico-sintering and mechanical properties. However, such technical properties of the archaeological clay brick samples of Kathmandu valley (Ghale et al., 2019) and ceramic tiles (Budathoki et al., 2018a, 2018b) were studied by few research groups in Nepal. Considering these facts, the present research work was focused to carry out an investigation of the firing temperature effect on the physical properties of WA, AP, BD and one mechanical property, i.e., CS of total twenty eight fired clay brick samples using ASTM standards (ASTM C20-00, 2015; ASTM C1424-15, 2015) to find out their physico-mechanical properties.

\section{Materials and methods}

Firing of brick samples

Twenty five pieces of sun-dried clay brick sample specimens and three pieces of fired clay brick sample from Shiddi Vinaayak Chimney Vattaa Factory- Lalitpur of Kathmandu valley, Nepal were used to accomplish present research work. Twenty four, among these twenty five pieces of the sun-dried clay brick samples, were fired at $700^{\circ}, 750^{\circ}, 800^{\circ}$, $850^{\circ}, 900^{\circ}, 950^{\circ}, 1000^{\circ}$ and $1100^{\circ} \mathrm{C}$ with three pieces (i.e., specimen-1, specimen-2 and specimen-3) for each firing temperatures using muffle furnace maintaining two hours soaking period and remaining one piece of the sun-dried brick sample was used to estimate their physico-sintering and mechanical properties for comparison. The fired brick sample produced by factory itself is named as NB-FPr. The details about these clay brick samples used in the study are summarized in Table I.

\section{Estimation of physical properties}

It is meaningful for mentioning here that the mineralogy of these ten brick samples was previously reported to be consisted mainly of quartz, feldspars, spinel, primary mullite and hematite including muscovite type of mica minerals (Bohara et al., 2018). In this study, three physical properties of the fired- brick samples were estimated using following equations (2), (3) and (4) in accordance with ASTM C20-00 standards (ASTM C20-00, 2015), where $\mathrm{W}_{\mathrm{D}}$ is dry weight $(\mathrm{g}), \mathrm{W}_{\mathrm{S}}$ is saturated weight $(\mathrm{g})$ and $\mathrm{V}_{\mathrm{b}}$ is volume of outer sides $\left(\mathrm{cm}^{3}\right)$ of the brick specimens.

Water absorption $(\%)=\frac{\mathrm{W}_{\mathrm{S}}-\mathrm{W}_{\mathrm{D}}}{\mathrm{W}_{\mathrm{D}}} \times 100$

Apparent porosity $(\%)=\frac{\mathrm{W}_{\mathrm{S}}-\mathrm{W}_{\mathrm{D}}}{\mathrm{V}_{\mathrm{b}}} \times 100$

Bulk density $\left(\mathrm{g} / \mathrm{cm}^{3}\right)=\frac{\mathrm{W}_{\mathrm{D}}}{\mathrm{V}_{\mathrm{b}}}$

Table I. Details about the clay brick samples used in this study

\begin{tabular}{lcl}
\hline Name of brick samples & Firing temperature $\left({ }^{\circ} \mathrm{C}\right)$ & Remarks \\
\hline NB-0 & - & Sun-dried brick \\
NB-700 & 700 & Fired at muffle furnace \\
NB-750 & 750 & Fired at muffle furnace \\
NB-800 & 800 & Fired at muffle furnace \\
NB-850 & 850 & Fired at muffle furnace \\
NB-900 & 900 & Fired at muffle furnace \\
NB-950 & 950 & Fired at muffle furnace \\
NB-1000 & 1000 & Fired at muffle furnace \\
NB-1100 & 1100 & Fired at muffle furnace \\
NB-FPr & Unknown & Fired at factory \\
\hline
\end{tabular}




\section{Estimation of compressive strength}

The compressive strength (CS) of the clay bricks was estimated using the RAM DIA 222-2 mm with maximum load of $2000 \mathrm{KN}$ compression testing (CT) machine available at the Central Material Testing Laboratory, Department of Civil Engineering of Pulchowk Engineering Campus, Tribhuvan University, Lalitpur using equation (5) in accordance with ASTM C1424-15 standards (ASTM C1424-15, 2015) as given below.

$$
\begin{aligned}
& \text { Compressive strength }\left(\mathrm{N} / \mathrm{mm}^{2}\right) \\
& =\frac{\text { Maximum load at failure }(\mathrm{N})}{\text { Average area of bed face }\left(\mathrm{mm}^{2}\right)}
\end{aligned}
$$

For the CT test, the clay bricks were immersed in water at room temperature for 24 hours and then the samples were removed from the water. The surplus water of the sample surface was drained out using smooth moisten cloth at room temperature. The unevenness observed also removed for the smooth parallel faces. The capping was subjected to the CT machine to estimate the compressive strength of the clay bricks.

\section{Results and discussion}

Firing temperature effect on physical properties

Different physico-mechanical properties of the fired brick bodies are reported to be mostly influenced by their mineralogical composition and firing temperature (Karhu et al., 2019; Johari et al., 2010; Karaman et al., 2006; Braganca \& Bergmann, 2003). For example, fluxing oxides contained in brick clay materials play one of the very important roles for the improvement of physico-mechanical properties of the fired-brick bodies (Sokolar et al., 2017, Sokolar \& Vodova 2015; Alcantara et al., 2008). Some basic physico-sintering properties of water adsorptivity, bulk density and apparent porosity and some mechanical properties of flexural and compressive strength act as the quality control parameters of the clay products like tiles (Budhathoki et al., 2018a).

To assess the quality of the clay bricks production in Kathmandu valley, the firing temperature effect on their some important physico-sintering properties is mostly considered and different physico-sintering properties should be correlated with their mechanical strength of compressive strength. It was reported that water absorption capacity became one of the important criteria for showing high quality and good strength of clay bodies like tiles (Budhathoki et al., 2018a). Consequently, it can be assumed that a lower amount of water retention capacity is always in demand for good quality brick production.

\section{Change in water absorption capacity of brick sample with firing temperature}

Figure 1 shows the effect of firing temperature on the water absorption capacity of all test specimens and their average

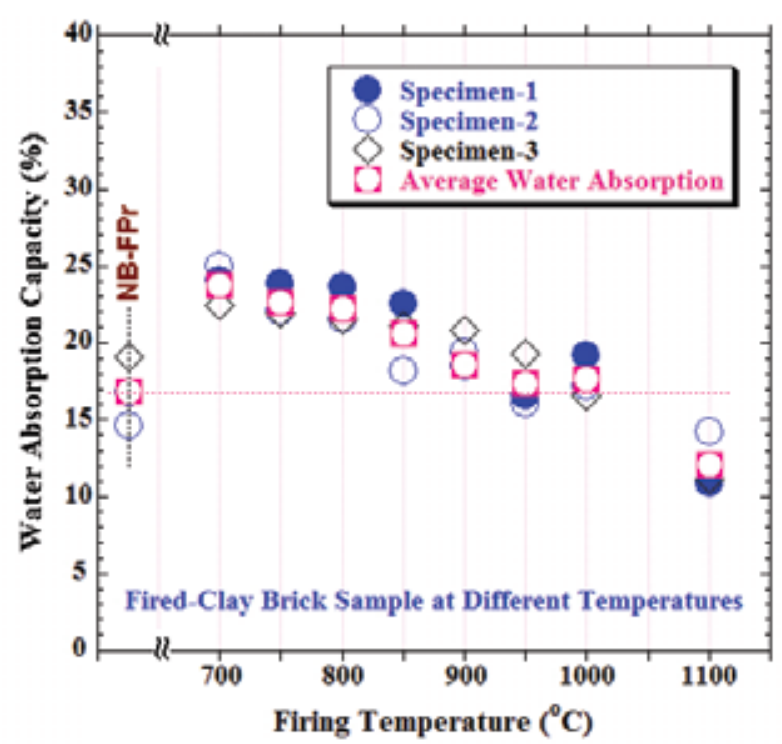

Fig. 1. Changes in the water absorption capacity of the clay brick samples as a function of firing temperature

values of the fired clay brick samples. The fired clay brick samples used in this study showed 11-25\% water absorption capacity. A slight decrease in the water adsorptivity with increasing the firing temperature of the clay brick samples fired up to $1000^{\circ} \mathrm{C}$ is clearly observed (Fig. 1). The water absorption capacity of the brick sample fired at $700^{\circ} \mathrm{C}$ is slightly higher than that of the fired brick sample at about $1000^{\circ} \mathrm{C}$ in laboratory and produced by the brick factory itself, i.e., NB-FPr sample. It is meaningful for mentioning here the facts that the brick samples fired between $900^{\circ}$ and $1000^{\circ} \mathrm{C}$ have almost same amounts of water absorption capacity as compared with the brick sample produced by the brick factory using their chimney. Consequently, it can be said that the brick samples produced by the brick factories of Kathmandu might be fired at around $900^{\circ}$ to $1000^{\circ} \mathrm{C}$.

\section{Change in bulk density of brick sample with firing temperature}

Results of the estimated bulk density of total twenty eight fired brick specimens at different temperatures are shown in Fig. 2 which cleared that the twenty four fired brick 
specimens at eight different temperatures between $700^{\circ}$ to $1100^{\circ} \mathrm{C}$ show $1.54-1.77 \mathrm{~g} / \mathrm{cm}^{3}$ of bulk density; while the brick sample NB-FPr (produced by brick factory) show about $1.71 \mathrm{~g} / \mathrm{cm}^{3}$ only. It is meaningful to mention here that the densification behavior was reported as function of firing temperature of the ceramic bodies (Budhathoki et al., 2018a) and hence the densification of the presently analyzed brick samples attained the maximum value at temperatures between $900^{\circ}$ and $1100^{\circ} \mathrm{C}$ and hence fired-brick samples at this temperature range show maximum bulk density as depicted in Fig. 2.

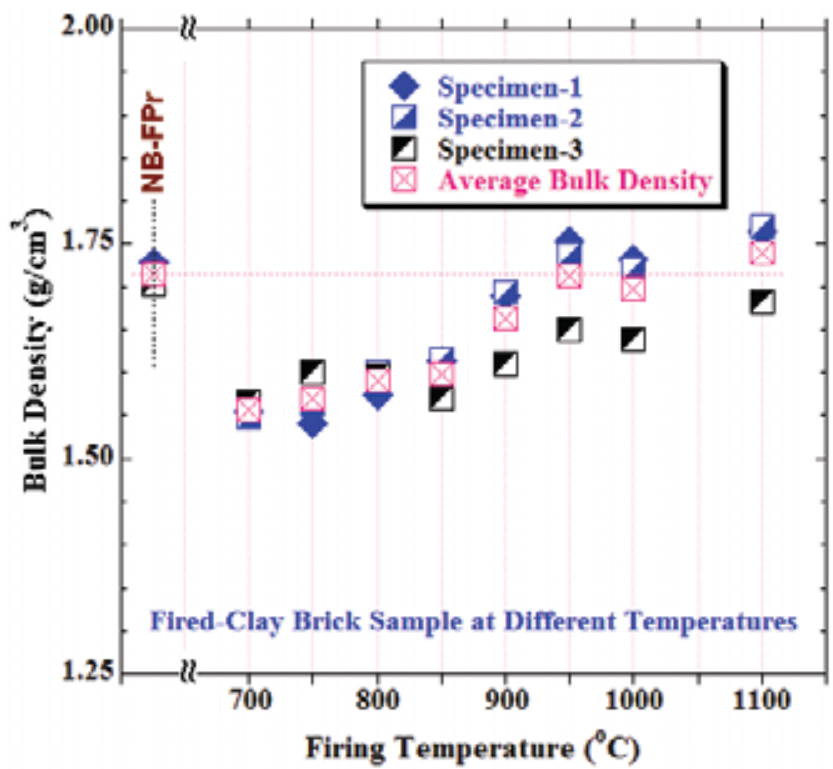

Fig. 2. Changes in the bulk density of the clay brick sample specimens as a function of firing temperature

Change in apparent porosity of brick sample with firing temperature

Similarly, the effect of firing temperature on the apparent porosity of all specimens and their average values of the fired clay brick samples is depicted in Fig. 3. All the fired clay brick samples showed the apparent porosity between $16-39 \%$ and a slight decrease in the apparent porosity with increasing the firing temperature of the clay brick samples fired up to $1000^{\circ} \mathrm{C}$ is clearly observed (Fig. 3). However, the apparent porosity at $1100^{\circ} \mathrm{C}$ is significantly lower value than of the brick sample specimens fired at $1000^{\circ} \mathrm{C}$. It is meaningful for mentioning that the brick sample NB-FPr (produced by brick factory) shows the average apparent porosity about $27 \%$ only.
Figure 4 shows a clear co-relation between the water absorptivity, apparent porosity and bulk density of all the fired brick sample specimens used in the present work as a

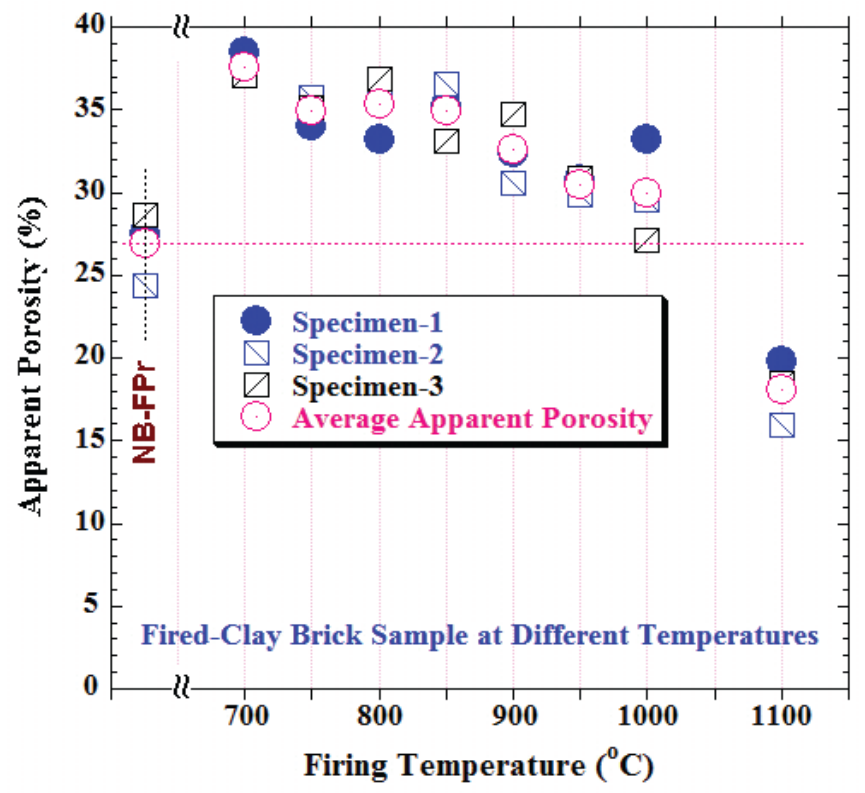

Fig. 3. Changes in the apparent porosity of the fired brick sample specimens as a function of firing temperature

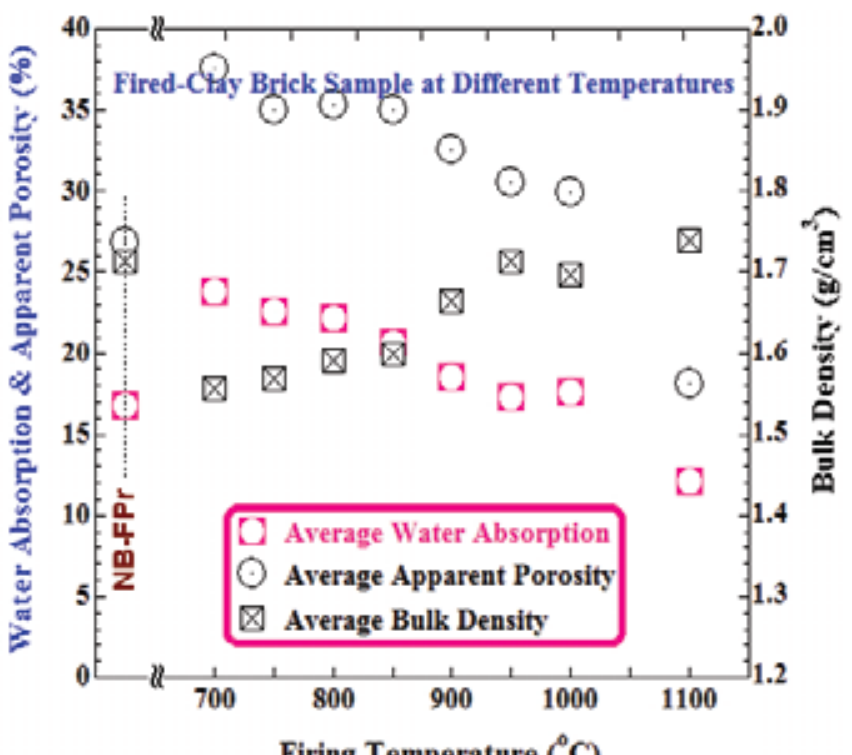

Fig. 4. Firing temperature effect on the water absorption capacity, apparent porosity and bulk density of the fired clay brick samples 
function of firing temperature. In most cases, it is observed that the fired ceramic bodies like tiles or bricks have high bulk density as well as the mechanical strength with low water absorption capacity as well as apparent porosity. From the present results, it is observed that there is a good correlation between the water absorptivity, apparent porosity, bulk density and firing temperature for all analyzed clay bricks. The water absorptivity and apparent porosity of the brick specimens decrease and the bulk density increases with increase of temperature as shown in Fig. 4. These results are mostly supported by the facts that the low density values observed for the brick structures at lower temperature are directly related to their high values of water absorptivity or apparent porosity with low particle packing in the clay bodies.

\section{Firing temperature effect on compressive strength}

Mechanical properties of the fired clay bricks play very important roles for their quality control. The worthy usages of bricks in structural and engineering applications depend mainly on their mechanical properties as well. Several standardized techniques were discussed for testing of the mechanical properties of ceramic bodies such as compressive strength (ASTM C1424-15, 2015), flexural strength (ASTM C1161-13, 2013) and static fracture toughness (ASTM C1421-16, 2016) and so on. However, measurement of the compressive strength is one of the most reliable techniques and is generally used for brittle and thick clay brick samples to assess their quality control.
Figure 5 shows the result of the estimated compressive strength of nine clay brick samples fired at different firing temperature. It is clear from the figure that the NB-FPr, i.e., the fired clay brick sample produced by the brick factory of Kathmandu valley using firing kiln of the brick factory, shows the maximum compressive strength of $17.55 \mathrm{MPa}$ than the compressive strength of other eight clay brick samples

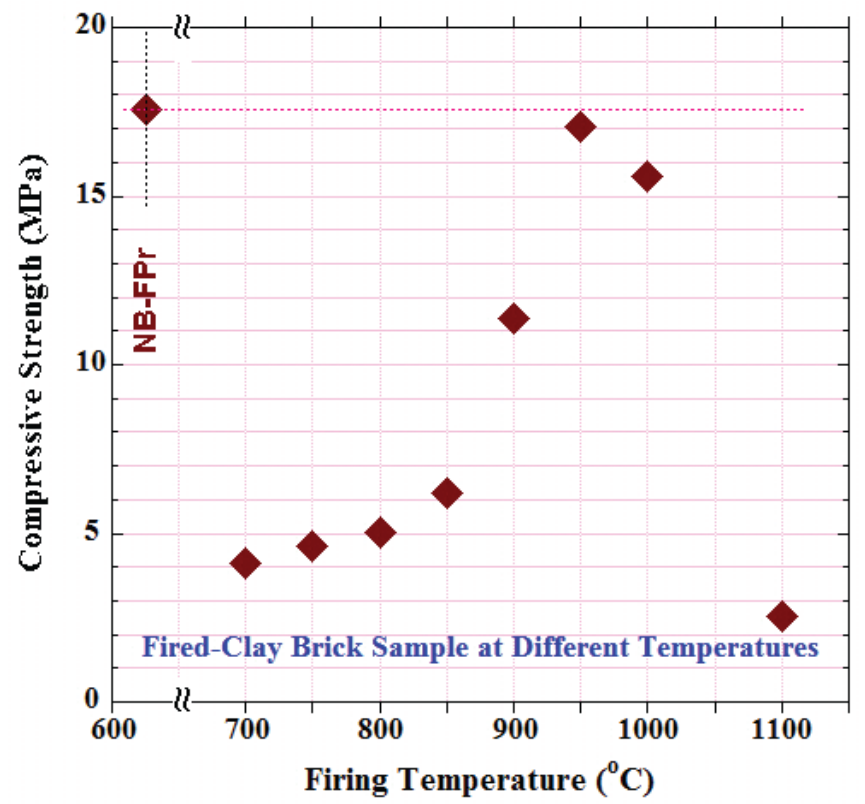

Fig. 5. Firing temperature effect on the compressive strength of the fired clay brick samples

Table II. Compressive strength of the fired brick samples at different temperatures

\begin{tabular}{ccc}
\hline Samples & Firing temperature $\left({ }^{\circ} \mathrm{C}\right)$ & Compressive strength $(\mathrm{MPa})$ \\
\hline NB-700 & 700 & 4.12 \\
NB-750 & 750 & 4.61 \\
NB-800 & 800 & 5.01 \\
NB-850 & 850 & 6.17 \\
NB-900 & 900 & 11.37 \\
NB-950 & 950 & 17.06 \\
NB-1000 & 1000 & 15.60 \\
NB-1100 & 1100 & 2.55 \\
NB-FPr & Factory produced & 17.55 \\
\hline
\end{tabular}


fired in the temperature range between $700^{\circ}$ to $1100^{\circ} \mathrm{C}$. The compressive strength of the fired clay brick samples used in this study is gradually increased with increasing the firing temperatures from $700^{\circ}$ to $950^{\circ} \mathrm{C}$ and it was found to be maximum compressive strength of $17.06 \mathrm{MPa}$ at $950^{\circ} \mathrm{C}$ as shown in Fig. 5. However, further increasing the firing temperature to produce the clay brick samples at $1100^{\circ} \mathrm{C}$, the compressive strength is significantly decreased to very low value of about $2.55 \mathrm{MPa}$ for NB-1100 brick sample as shown as well as in Fig. 5 and also in Table II.

Consequently, it can be said that the sintering mechanism of the clay brick sample at $700^{\circ}$ to $950^{\circ} \mathrm{C}$ firing temperature should be different than at $1000^{\circ} \mathrm{C}$ or high firing temperature. The dependence of the compressive strength on the firing temperature of clay brick materials does not exhibit a significant increase of the compressive strength at $1100^{\circ} \mathrm{C}$. At high firing temperature of $1100^{\circ} \mathrm{C}$, the compressive strength decreases significantly due to the softening of the clay brick materials and the formation of melt. The similar behavior was reported for aluminium oxide where the flexural strength was decreased with increasing the firing temperatures above $1000^{\circ} \mathrm{C}$, nevertheless, mullitic materials exhibited a maximum level of flexural strength at high temperatures (Urbánek et al., 2017).

The sintering processes of brick clay powders can be divided into two types: solid-state sintering at low firing temperature range and the liquid phase sintering comparatively at high temperature range as described elsewhere (Kang, 2005). The decrease of the mechanical strength as well as the physico-chemical properties of the electro-ceramic materials consisted of kaolin, aluminium oxide and feldspars was also reported by different research groups (Urbánek et al., 2017; Trnik et al., 2013; Stubna et al., 2009; Traore et $a l ., 2001)$. The NB-900, NB-950 and NB-1000 fired brick samples at $900^{\circ}, 950^{\circ}$ and $1000^{\circ} \mathrm{C}$ show the compressive strength of $11.37,17.06$ and $15.60 \mathrm{MPa}$, respectively, and remaining other five brick samples of NB-700, NB-750, NB-800, NB-850 and NB-1100 show the compressive strength less than $10 \mathrm{MPa}$. Furthermore, the CS of the brick sample fired at $950^{\circ}$ $\mathrm{C}$ is estimated almost same value as that of the factory produced brick sample, i.e., NB-FPr. These results revealed that the most suitable firing temperature to produce best quality of the clay brick sample using the raw clay raw materials of the brick factory of Kathmandu seems to be about $950^{\circ}-1000^{\circ} \mathrm{C}$.
Relation between physical properties and compressive strength

There is a good correlation between the compressive strength with all these three types of physical properties (i.e., water absorption capacity, apparent porosity and bulk density) of the entire analyzed clay brick sample specimens fired between $700^{\circ}$ to $1000^{\circ} \mathrm{C}$ temperatures as shown in Figs 6-8. The compressive strength at different firing temperatures of the clay brick samples is found to be increased exponentially with decreasing of water absorption capacity and apparent porosity as depicted in Figs 6 and 7, respectively, although the compressive strength of the clay brick samples is exponentially increase with slight increase of their bulk density as shown in Fig. 8 . Consequently, in order to improve the mechanical properties of the clay brick bodies, it can be said that the efforts need to focus on decreasing both the water absorption capacity and apparent porosity, and on increasing the bulk density as well, because these physico-sintering properties are responsible for the production of better quality clay brick samples and other ceramic bodies too. Moreover, figures 6-8 clearly show a good correlation between the compressive strength of the fired clay bricks with water absorption capacity, apparent porosity and bulk density, respectively. On the other hand, the compressive strength of the fired clay brick samples used in this study is directly correlated with the firing temperature as shown above in Fig. 5 and also summarized in Table II.

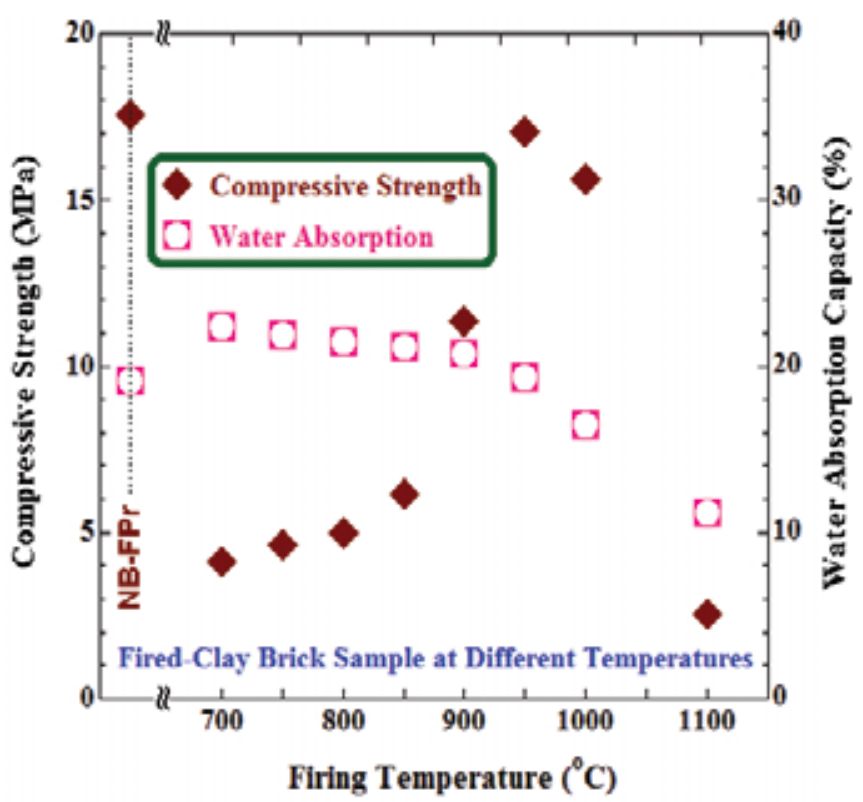

Fig. 6. Temperature effect on the compressive strength and water absorbtivity of the fired clay bricks 


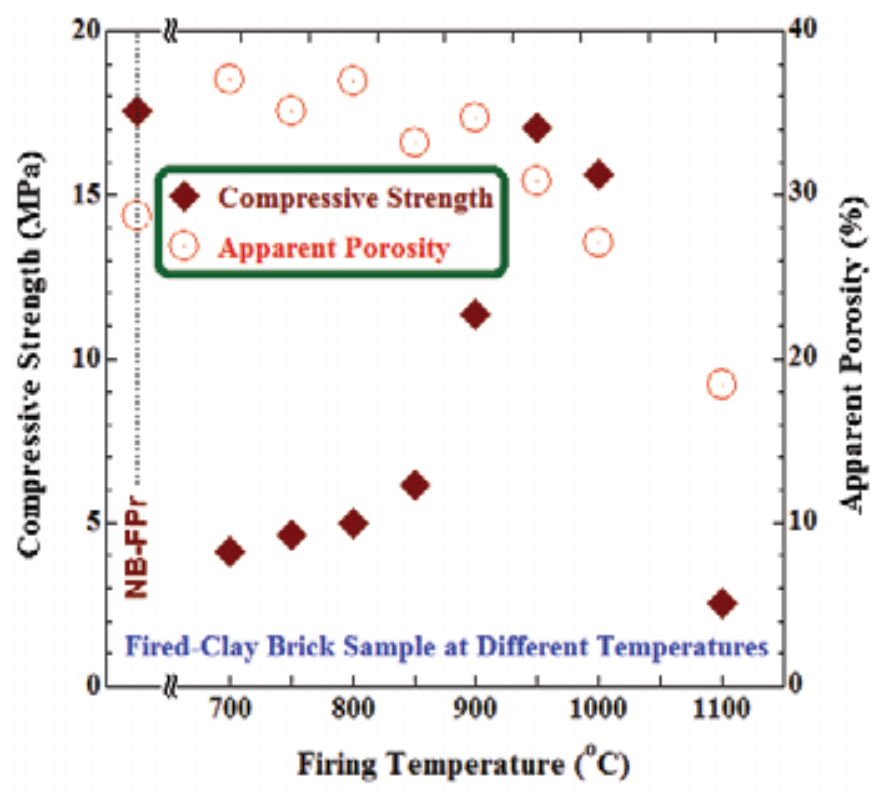

Fig. 7. Temperature effect on the compressive strength and apparent porosity of the fired clay bricks

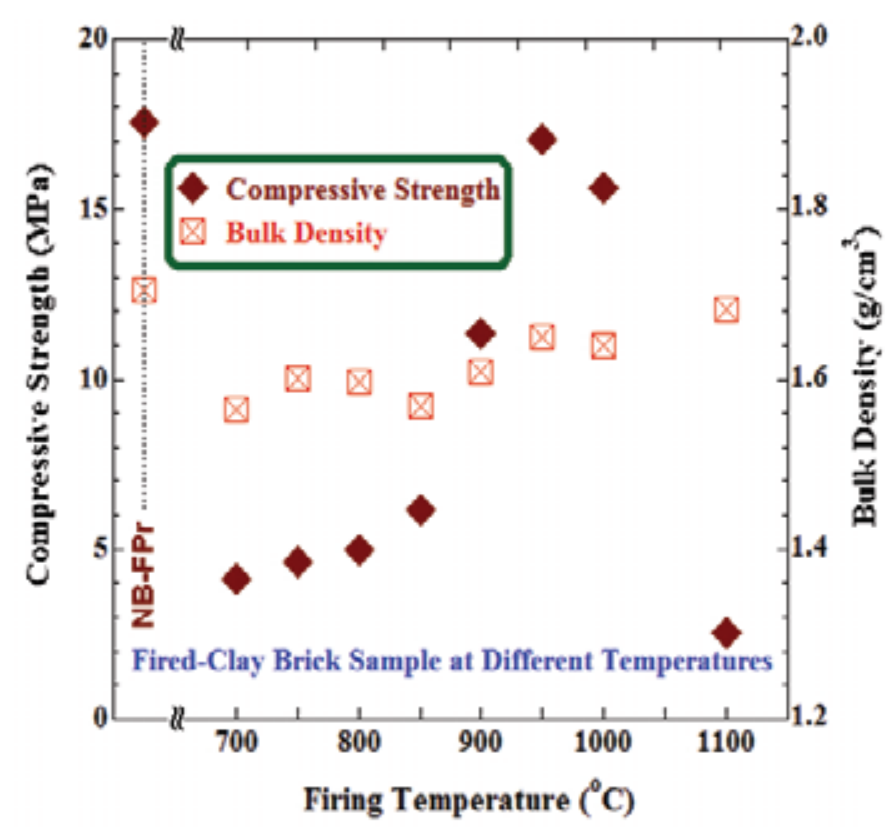

Fig. 8. Correlation between the compressive strength and bulk density of fired clay bricks

\section{Conclusion}

The present research work was focused to study the firing temperature effects on three different types of physico-sintering properties: water absorption capacity, apparent porosity and bulk density and one mechanical property, i.e., compressive strength of twenty seven clay brick sample specimens using ASTM standards. Following conclusions are drawn from the results and discussion.

i. The water absorption capacity and apparent porosity of the fired clay brick samples is found to be decreased, although the bulk density is increased with increasing the firing temperature in the range of $700^{\circ}$ to $1100^{\circ} \mathrm{C}$.

ii. The bulk density of the fired clay brick samples is found to be increased from 1.54 to $1.77 \mathrm{~g} / \mathrm{cm}^{3}$ with decreasing their water absorption from 25 to $11 \%$ and the apparent porosity from 39 to $16 \%$ as a function of firing temperature in the range of $700^{\circ}$ to $1100^{\circ} \mathrm{C}$.

iii. The most suitable firing temperature for producing of the better quality clay brick samples by local brick factory of Kathmandu valley seems to be in the range of $950^{\circ}-1000^{\circ} \mathrm{C}$ at which the maximum compressive strength of the bricks is reported in the range of 11 to $17 \mathrm{MPa}$.

iv. The compressive strength of the clay brick samples is found to be increased exponentially with decreasing the water absorption capacity and apparent porosity.

v. The physical properties are largely responsible for the betterment of the mechanical properties of the structural brick samples of Kathmandu valley and hence efforts need to focus on decreasing both water absorption capacity and porosity with increasing density in order to improve the compressive strength property.

\section{Acknowledgement}

The University Grants Commission-Nepal (UGC-Nepal) is highly acknowledged for providing the UGC Faculty Research Grant-2072/073 to conduct this research work in Central Department of Chemistry, Kirtipur.

\section{References}

Ajala AJ, Badarulzaman NA and Aramjat AB (2017a), Impact of sintering temperatures on microstructure, porosity and mechanical strength of refractory brick, Mater. Sci. Forum 888: 66-70. DOI: org/ 10.4028/www.scientific.net/MSF.888.66 
Ajala AJ, Badarulzaman NA and Aramjat AB (2017b), Influence of sintering temperatures on physico-mechanical properties and microstructure of refractory fireclay bricks, Int. J. Eng. Techno. 8(6): 2588-2593. DOI: org/10.21817/ijet/ 2016/ v8i6/160806214

Alcantara ACS, Beltrao MSS, Oliveira HA, Gimenez IF and Barreto LS (2008), Characterization of ceramic tiles prepared from two clays from Sergipe-Brazil, Appl. Clay Sci. 39(3-4): 160-165. DOI: org/10.1016/j.clay.2007.05.004

Aramide FO (2015), Effects of sintering temperature on the phase developments and mechanical properties ifon clay, Leonardo J. Sci. 26: 67-82.

ASTM C1161-13 (2013), Standard Test Method for Flexural Strength of Advanced Ceramics at Ambient Temperature- Annual Book of ASTM Standards, (ASTM International, West Conshohocken), 2013. DOI: 10.1520/C1161-13

ASTM C1421-16 (2016), Standard Test Methods for Determination of Fracture Toughness of Advanced Ceramics at Ambient Temperature- in Annual Book of ASTM Standards, (ASTM International, West Conshohocken), 2016. DOI: 10.1520/C1421-10

ASTM C1424-15 (2015), Standard Test Methods for Monotonic Compressive Strength of Advanced Ceramics at Ambient Temperature- Annual Book of ASTM Standards, Vol. 15.01, (ASTM International, West Conshohocken), 2015. DOI: 10.1520/ C1424-15

ASTM C20-00 (2015), Standard Test Methods for Apparent Porosity, Water Absorption, Apparent Specific Gravity and Bulk Density of Burned Refractory Brick and Shapes by Boiling WaterAnnual Book of ASTM Standards, Vol. 15.01, (ASTM International, West Conshohocken), DOI: 10.1520/C0020-00R15

Bohara NB, Ghale DB, Bhat LB, Duwal N and Bhattarai J (2018), Investigation of the firing temperature effects on clay brick sample; part-I: mineralogical phase characterization, Bibechana 16: 122-130. DOI: 10.3126/bibechana.v16i0.21319
Bordia RK and Camacho-Montes H (2012), Sintering: Fundamentals and Practice, in Ceramics and Composites Processing Methods, Part-1: Densification Eds. Bansal NP and Boccaccini AR, $1^{\text {st }}$ Ed. The American Ceramic Society, John Wiley and Sons, Inc., pp 3-42.

Braganca SR and Bergmann CP (2003), A view of whitewares mechanical strength and microstructure, Ceram. Int. 29(7): 801-806. DOI: 10.1016/ S0272-8842(02)00234-1

Budathoki P, Duwal N and Bhattarai J (2018a), Investigation on physico-sintering and mechanical properties of clay tiles Available in Kathmandu valley of Nepal, Asian J. Chem. 30(11): 2515-2520. DOI: 10.14233 /ajchem.2018.21509

Budathoki P, Poudyal G, Oli RR, Duwal N and Bhattarai J (2018b), Assessment on the characterization of mineralogical phase of ceramic tiles available in Kathmandu valley (Nepal) using XRD and FTIR analyses, Int. J. Appl. Sci. Biotech. 6(3): 238-243. DOI: $10.3126 /$ ijasbt.v6i3.21171

Callister Jr. WD (2007), Materials Science and Engineering, $10^{\text {th }}$ Ed. John Willey \& Sons, Inc. Hoboken, NJ, pp 451-453.

Coble RL and Kingery WD (1956), Effect of porosity on physical properties of sintered alumina, J. Am. Ceram. Soc. 39(11): 377-385. DOI: / 10.1111/ j.1151-2916.1956.tb15608.x

Dodoo-Arhin D, Konadu DS, Annan E, Buabeng FP, Yaya A and Agyei-Tuffour B (2013), Am. J. Mater. Sci., 3(5): 110-119. DOI: 10.5923/j.materials. 20130305.02

Dondi M, Marsigli M and Venturi L (1999), Microstructure and mechanical properties of clay bricks: comparison between fast firing and traditional firing, Brit. Ceram. Trans. 98(1): 12-18. DOI: $10.1179 / 096797899680183$

Dunham AC, McKnight AS and Warren I (2001), Mineral assemblages formed in Oxford clay fired under different time-temperature conditions with reference to brick manufacture, Proc. Yorkshire 
Geol. Soc. 53(3): 221-230. DOI: $10.1144 /$ pygs.53.3.221

Fernandes FM, Lourenço PB and Castro F (2010), Ancient Clay Bricks: Manufacture and Properties, in Materials, Technologies and Practice in Historic Heritage Structures, Ed.s Dan MB, Přikryl R and Török Á, Springer, Dordrecht, pp 29-48. DOI: 10.1007/978-90-481-2684-2_3

Ghale DB, Bohara NB, Duwal N and Bhattarai J (2019), Investigation on the mineralogical phase of ancient brick samples of Kathmandu valley (Nepal) using XRD and FTIR analysis, Rasayan J. Chem. 12(2): 402-408. DOI: 10.31788/RJC.2019.1224034

Ghorbel A, Fourati M and Bouaziz J (2008), Microstructural evolution and phase transformation of different sintered kaolins powder compacts, Mater. Chem. Phys. 112(3): 876-885. DOI: 10.1016/j.matchemphys.2008.06.047

Johari I, Said S, Hisam B, Bakar A and Ahmad ZA (2010), Effect of the change of firing temperature on microstructure and physical properties of clay bricks from Beruas (Malaysia), Sci. Sint. 42(2): 245-254. DOI: $10.2298 / \operatorname{SOS} 1002245 \mathrm{~J}$

Kang SL (2005), Sintering: Densification, Grain Growth and Microstructure, Elsevier, Oxford.

Karaman K, Ersahin S and Gunal HJ (2006), Firing temperature and firing time influence on mechanical, physical properties of clay bricks, $J$. Sci. Indus. Res. $\mathbf{6 5}(2)$ : 153-159. https://nopr.niscair.res.in/handle/123456789/4811

Karhu M, Lagerbom J, Solismaa S, Honkanen M, Ismailov A, Räisänen ML, Huttunen-Saarivirta E, Levänen E and Kivikytö-Reponen P (2019), Mining tailings as raw materials for reaction-sintered aluminosilicate ceramics: Effect of mineralogical composition on microstructure and properties, Ceram. Int. 45(4): 4840-4848. DOI: 10.1016/j.ceramint. 2018.11.180

Martin-Marquez J, Rincon JM and Romero M (2010), Effect of microstructure on mechanical properties of porcelain stoneware, J. Eur. Ceram. Soc. 30(15): 3063-3069. DOI: $10.1016 /$ j.jeurceramsoc. 2010.07 .015
Mostaghelchi M, Zahiri R, Miremad SH and Ebadi AG (2013), Use of mica mineral powder in bricks industry to improve the performances, Asian J. Chem. 25(16): 9144-9148. DOI: 10.14233/ ajchem.2013.15053C

Njoya D, Tadjuidje FS, Ndzana EJA, Pountouonchi A, Tessier-Doyen N and Lecomte-Nana G (2017), Effect of flux content and heating rate on the microstructure and technological properties of Mayouom (Western-Cameroon) kaolinite clay based ceramics, J. Asian Ceram. Soc. 5(4): 422-426. DOI: 10.1016/j.jascer.2017.09.004

Rasmussen KL, De La Fuente GA, Bond AD, Matheesen KK and Vera SD (2012), Pottery firing temperatures: a new method for determining the firing temperature of ceramics and burnt clay, $J$. Arch. Sci. 39(6): 1705-1716. DOI: 10.1016/j.jas.2012.01.008

Sokolar R and Vodova L (2015), Sintering of feldspar rocks from Czech quarries, J. Ceram. Soc. Jpn. 123(1): 62-67. DOI: $10.2109 /$ jcersj2.123.62

Sokolar R, Kersnerovv L and Sveda M (2017), The effect of different fluxing agents on the sintering of dry pressed porcelain bodies, J. Asian Ceram. Soc. 5(3): 290-294. DOI: 10.1016/j.jascer. 2017.06.001

Stubna I, Trník A and Vozar L (2009), Thermo-mechanical and thermo-dilatometric analysis of green alumina porcelain, Ceram. Int. 35(3): 1181-1185. DOI: $10.1016 /$ j.ceramint. 2008.05.004

Traore K, Kabre TS and Blanchart P (2001), Sintering of a clay from Burkina Faso by dilatometry influence of the applied load and the pre-sintering heating rate, Ceram. Int. 27(8): 875-882. DOI: 10.1016/ S0272-8842(01)00043-8

Trnik A, Moravcikov J, Keppert M and Medved I (2013), Investigation of sintering in electroceramics by thermodilatometry, Sci. Sinter. 45(1): 3-12. DOI: 10.2298/SOS1301003T

Urbánek J, Hamácek J, Machácek J, Kutzendörfer and Hubálková J (2017), Thermomechanical properties 
of mullitic materials, Process. Appl. Ceram. 11(4): 322-328. DOI: 10.2298/PAC1704322U

Velraj G, Janaki K, Musthafa AM and Palanivel R (2009), Estimation of firing temperature of some archaeological pottery shreds excavated recently in Tamilnadu, India, Spectrochimica Acta Part-A: Mol. Biomol. Spectros. 72(4): 730-733. DOI: 10.1016/ j.saa.2008.11.015
Yongue-Fouateu R, Ndimukong F, Njoya A, Kunyukubundo F and Mbih PK (2016), The Ndop plain clayey materials (Bamenda area-NW Cameroon): Mineralogical, geochemical, physical characteristics and properties of their fired products, J. Asian Ceram. Soc. 4(3): 299-308. DOI: 10.1016/ j.jascer.2016.05.008 